\title{
Assessment of the Water Quality of Oji River Using Water Quality Index (WQI)
}

\author{
Uzochukwu Cornelius Ugochukwu* Amaka Lynda Onuorah Onyechi Henry Onuora \\ Shell/UNN Centre for Environmental Management \& Control, \\ University of Nigeria, Enugu Campus, Nigeria
}

\begin{abstract}
This study measured the physico-chemical parameters and concentration of the heavy metals of Oji river and assessed the water quality of the river by means of water quality index (WQI). The physico-chemical parameters were determined following the APHA (1998) procedure and the heavy metals were analyzed using Atomic Absorption Spectrometry (AAS). The results of this study revealed that the WQI of the river in the various locations studied varied from 241-830 for the rainy season indicating 'poor' to 'unsuitable for drinking' whereas the WQI varied from 68-946 for the dry season indicating 'good' to 'unsuitable for drinking'. It was only the location down-steam the Power Station in the dry season that was ranked good. The main contaminants that accounted for the poor quality of the river for drinking purposes were lead, cadmium and hydrocarbons. The Abattoir appears to be mainly responsible for the input of the heavy metals into the river.
\end{abstract}

Keywords: Water quality; water quality index; contaminants, river, heavy metals, physico-chemical parameters. DOI: $10.7176 / \mathrm{JEES} / 9-1-10$

\section{INTRODUCTION}

Surface water bodies constitute important water resources for human society and deserve to be well managed. Water resources play vital role in the socio-economic development of any society in addition to ecosystem services they provide if their source is surface water body. The common sources of surface water include ponds, streams, lakes and rivers. Surface water is susceptible to contamination given its openness to all manner of influences. Example, anthropogenic activities such as agricultural activities and industrial effluent discharge can significantly alter the quality of a surface water body (Singh et al., 2005; Todd et al., 2012).

Surface water can be used for various purposes including bathing, washing, irrigation, drinking etc. However, surface water for drinking purposes would need to pass a more stringent water quality tests as the water quality criteria for drinking purposes is more demanding. The use of surface water bodies for drinking purposes by various rural communities even when the quality of the water is not confirmed for portability is common (Ahmad et al., 2004).

If water resources are not adequately monitored and protected, humans would face serious water crisis due to scarcity and this would further compound the problem already stated by WHO (2008) that over 1 billion people all over the world do not have access to a reliable drinking water source. The water quality of surface water bodies can vary widely even in the same region depending on the anthropogenic activities and other factors that interact with the water body. Also, water quality of a given river can vary according to spatial and temporal dimensions, necessitating well designed study that captures the factors responsible for all temporal and spatial variations in water quality (Qadir et al., 2008; Wu et al., 2018).

Water quality index (WQI) is one of the methods used in the assessment of water quality especially for groundwater and surface water bodies such as rivers. Its ability to combine several environmental parameters to a single unitless value offers a rapid means of evaluation and comparison of water quality of several water systems (Wu et al., 2018). Several studies have been carried out in several regions of the world to assess water quality of water systems including lotic systems such as rivers using WQI (Lumb et al., 2011; Iyama and Edori, 2013; Sutadian et al., 2016; Wu et al., 2018). However, the WQI of Oji river in Enugu State Nigeria especially as affected by anthropogenic activities such as Abattoir and Power Station is not reported yet. This study is therefore aimed at investigating on spatial and temporal basis, how that some of the activities that take place around the river which are anthropogenic nature may be impacting the water quality of the river. To this effect, the study was carried out during the rainy and dry season and covering distances that factor in the influence of the identified anthropogenic activities such as the Abattoir and Power Station.

\section{MATERIALS AND METHODS 2. MATERIALS AND METHODS} 2.1 Study Area

The study area is in Oji River Local Government Area (Figure 1). Oji River local government area occupies about $400 \mathrm{Km}^{2}$ land area with a population of 126,587 going by the 2006 population census. The geographical location is between latitude $6^{0} 14^{\prime} \mathrm{N}$ and $6^{0} 20^{\prime} \mathrm{N}$ and between longitude $7^{0} 17^{\prime} \mathrm{E}$ and $7^{0} 21^{\prime} \mathrm{E}$. The entire area is a tropical rain forest with temperature ranging between 27 and $32{ }^{\circ} \mathrm{C}$. The geology of the area comprises $330 \mathrm{~m}$ 
thick Ajali formation that is underlain by $400 \mathrm{~m}$ thick Mamu- and $200 \mathrm{~m}$ thick Nkporo formations. Rainy season (April - October) and dry season (November-March) are the two seasons in Nigeria especially the southern part of Nigeria where the study area is located. Oji river is a fast flowing river and receives waste discharges from several anthropogenic activities such as abattoir, power plants, agricultural run-off etc.

The study area and sampling locations are as presented in Figure 1.

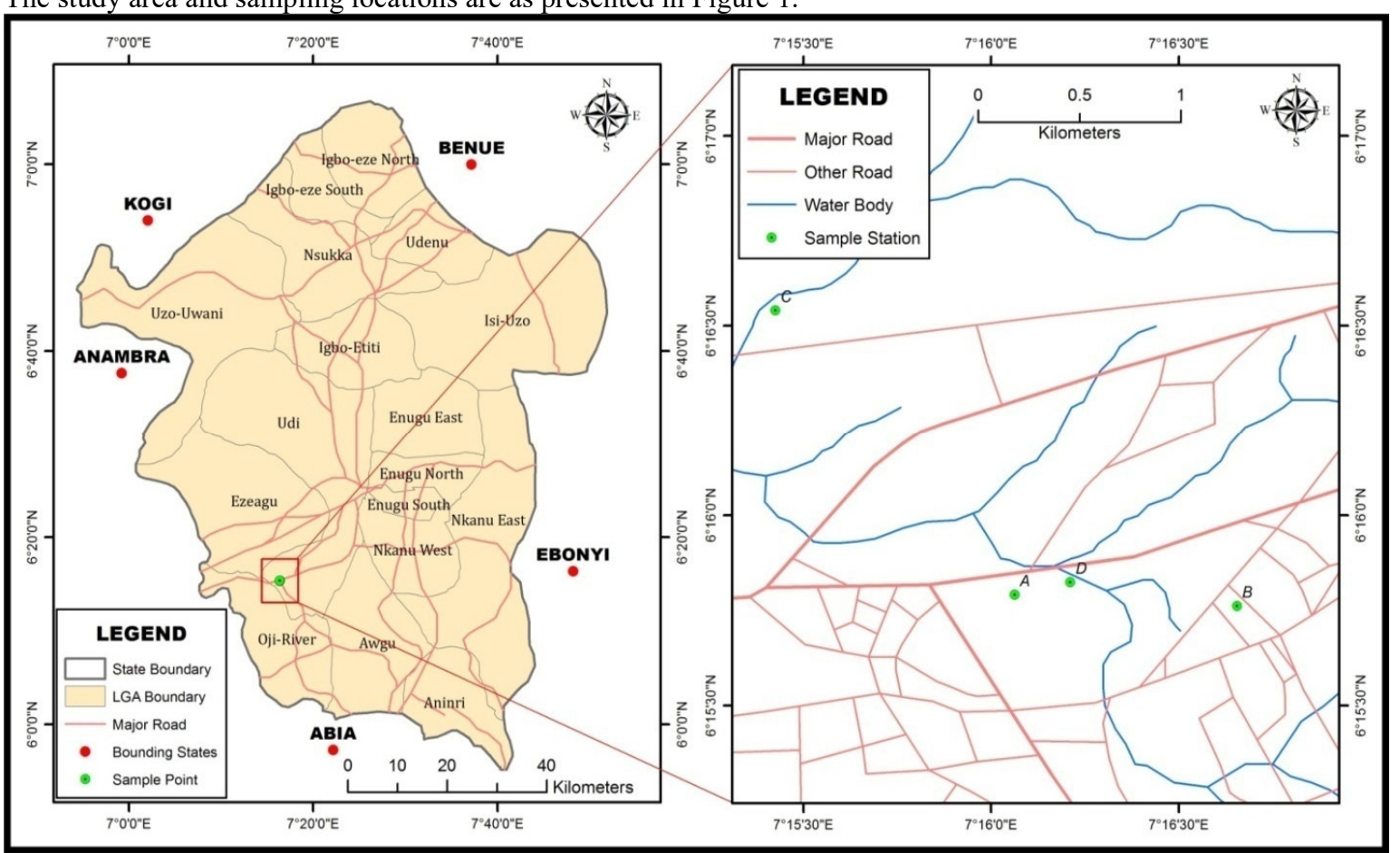

Figure 1 Map of the study area showing sampling locations, A,B,C and D covering a distance of about $1 \mathrm{~km}$.

\subsection{Sampling}

Sampling was carried out in October, 2017 and January, 2018 covering both the wet and dry seasons. Samples were collected every two weeks for each month and in triplicates. The sampling locations were carefully selected to isolate effect of discharges from two major different activities, viz, abattoir and defunct coal power station. Sampling location A is about $250 \mathrm{~m}$ upstream the abattoir while sampling location B is by the Abattoir. Sampling location $\mathrm{C}$ is about $450 \mathrm{~m}$ downstream the Abattoir and about $100 \mathrm{~m}$ upstream the defunct coal power plant. Sampling location D is about $250 \mathrm{~m}$ downstream the coal power plant. Water samples were collected at the river-water column. The water samples were collected into a $1 \mathrm{~L} \mathrm{HNO}_{3}$ pre-washed polyethylene containers. Preservation of the heavy metals in the water samples was achieved by acidifying the samples using $5 \mathrm{~mL}$ of $6 \mathrm{M}$ $\mathrm{HNO}_{3}$ prior to transportation to the laboratory for analysis. The water samples were held in a sampling box filled with ice cubes for maintaining sample temperature below $4{ }^{\circ} \mathrm{C}$ and transported to the laboratory for analysis.

\subsection{Laboratory analysis}

\subsubsection{Analysis of water samples}

The physic-chemistry parameters such as electrical conductivity (EC), $\mathrm{pH}$, total dissolved solids (TDS), chloride $(\mathrm{Cl})$, sulphate $\left(\mathrm{SO}_{4}\right)$ and nitrate $\left(\mathrm{NO}_{3}\right)$ were analyzed following APHA (1998) standard procedure. The total organic carbon (TOC) was analyzed by means of a TOC analyzer. The heavy metals $(\mathrm{Cu}, \mathrm{Zn}, \mathrm{Cr}, \mathrm{Pb}, \mathrm{Cd}$ were analyzed using SensAA GBC Flame Atomic absorption spectrometer.

\subsection{Water quality index (WQI)}

Sahu and Sikdar (2008) procedure of estimating WQI was adopted in this study:

a) Weight $\left(\mathrm{w}_{\mathrm{i}}\right)$ assignment based on the health effects of the parameters.

Assigned weight is between 1 and 5. The parameters that are of major importance are assigned highest weight whereas those that are of minor importance are assigned low weight. Hence, cadmium, lead, nitrate and fluoride are assigned a weight of 5 each whereas copper and iron are assigned 2 and 3 respectively. See Table 1 for detailed weights as assigned. 
b) Relative weight $\left(\mathrm{W}_{\mathrm{i}}\right)$

The relative weight $\left(\mathrm{W}_{\mathrm{i})}\right)$ is computed as follows:

$\mathrm{W}_{\mathrm{i}}=\mathrm{W}_{\mathrm{i}} / \Sigma \mathrm{W}_{\mathrm{i}}$

Where: $\mathrm{w}_{\mathrm{i}}$ is the arbitrarily assigned weight based on the above described criterion.

c) Assignment of quality rating scale

$\mathrm{q}_{\mathrm{i}}=\left(\mathrm{C}_{\mathrm{I}} / \mathrm{S}_{\mathrm{i}}\right)^{*} 100$

$\mathrm{q}_{\mathrm{i}}=$ quality rating scale; $\mathrm{C}_{\mathrm{I}}=$ concentration in water sample of the parameters

$\mathrm{S}_{\mathrm{i}}=$ Standard organization of Nigeria (SON) standard for each chemical parameter.

d) Computation of Water quality sub-index (SI)

The water quality sub-index is computed as follows:

$\mathrm{SI}=\mathrm{W}_{\mathrm{i}}^{*} \mathrm{q}_{\mathrm{i}}$

e) Determination of water quality index (WQI)

$\mathrm{WQI}=\Sigma \mathrm{SI}$ Eq. 4

The weight and the relative weight of the parameters used in determining the WQI is as presented in Table 1.

Table 1: Weight and relative weight for determining WQI

\begin{tabular}{|l|l|l|l|}
\hline Parameters & SON Standard & $\mathrm{W}_{\mathrm{i}}$ & $\mathrm{W}_{\mathrm{i}}$ \\
\hline $\mathrm{pH}$ & $6.5-8.5(7.5)^{\mathrm{a}}$ & 4 & 0.091 \\
\hline $\mathrm{TDS} \mathrm{mg} / \mathrm{L}$ & 500 & 4 & 0.091 \\
\hline $\mathrm{Cl} \mathrm{mg/L}$ & 250 & 3 & 0.068 \\
\hline $\mathrm{TOC} \mathrm{mg/L}$ & 5 & 5 & 0.1136 \\
\hline $\mathrm{SO}_{4} \mathrm{mg} / \mathrm{L}$ & 100 & 3 & 0.068 \\
\hline $\mathrm{NO}_{3} \mathrm{mg} / \mathrm{L}$ & 50 & 5 & 0.1136 \\
\hline $\mathrm{Cr} \mathrm{mg} / \mathrm{L}$ & 0.3 & 3 & 0.068 \\
\hline $\mathrm{Pb} \mathrm{mg/L}$ & 0.01 & 5 & 0.1136 \\
\hline $\mathrm{Cu} \mathrm{mg/L}$ & 1 & 2 & 0.0454 \\
\hline $\mathrm{Cd} \mathrm{mg/L}$ & 5 & 0.1136 \\
\hline $\mathrm{EC} \mu \mathrm{S} / \mathrm{cm}$ & 0.003 & 5 & 0.1136 \\
\hline & 1000 & $\Sigma=44$ & $\Sigma=1$ \\
\hline
\end{tabular}

$\mathrm{a}=$ mean value

The $\mathrm{w}_{\mathrm{i}}$ values are adapted from Sahu and Sikdar (2008).

Water quality ranking using WQI is based on the following scheme: < 50 implies excellent water; 50-100 implies good water; 100-200 implies poor water; 200-300 implies very poor water; $>300$ implies water unsuitable for drinking (Sahu and Sikdar, 2008)

\section{RESULTS AND DISCUSSIONS}

3.1 Values of the water quality parameters

The values of the water quality parameters are as presented in Table 2.

Table 2 Values of the physico-chemical parameters and concentration of the heavy metals for the months of October, 2017 and January, 2018.

\begin{tabular}{|c|c|c|c|c|c|c|c|c|c|c|c|}
\hline \multirow[t]{3}{*}{ Location } & \multicolumn{11}{|c|}{ Values of Parameters for October 2017} \\
\hline & \multirow[t]{2}{*}{$\mathrm{pH}$} & EC & TDS & $\mathrm{Cl}$ & $\mathrm{SO}_{4}$ & $\mathrm{NO}_{3}$ & TOC & $\mathrm{Cr}$ & $\mathrm{Pb}$ & $\mathrm{Cu}$ & $\mathrm{Cd}$ \\
\hline & & $\mu \mathrm{S} / \mathrm{cm}$ & \multicolumn{9}{|l|}{$\mathrm{mg} / \mathrm{L}$} \\
\hline A & 6.5 & 7.4 & 4.1 & 2.1 & 1.5 & 0.4 & 20 & 0.012 & 0.25 & 0.015 & 0.0065 \\
\hline $\mathrm{B}$ & 6.1 & 9.0 & 4.75 & 2.4 & 1.6 & 0.4 & 15 & 0.23 & 0.18 & 0.024 & 0.034 \\
\hline $\mathrm{C}$ & 6.8 & 14.8 & 7.8 & 3.2 & 1.9 & 0.3 & 25 & BDL & 0.038 & BDL & 0.035 \\
\hline $\mathrm{D}$ & 6.4 & 18.1 & 10.8 & 4.1 & 2.1 & 0.4 & 300 & 0.013 & 0.12 & BDL & 0.033 \\
\hline \multicolumn{12}{|c|}{ Values of Parameters for January 2018} \\
\hline A & 5.9 & 13.5 & 7.2 & 2.7 & 1.6 & 0.25 & 10 & 0.006 & 0.062 & BDL & 0.006 \\
\hline $\mathrm{B}$ & 6.1 & 15.3 & 7.8 & 3.1 & 1.7 & 0.35 & 10 & 0.07 & 0.23 & 0.25 & 0.17 \\
\hline $\mathrm{C}$ & 6.0 & 12.8 & 7.0 & 2.8 & 1.6 & 0.2 & 10 & BDL & 0.14 & BDL & 0.11 \\
\hline $\mathrm{D}$ & 6.4 & 12.9 & 7.0 & 2.8 & 1.6 & 0.35 & 15 & 0.005 & 0.005 & 0.01 & 0.005 \\
\hline
\end{tabular}

$\mathrm{BDL}=$ Below Detection Limit

In the rainy season, the electrical conductivity (EC) varied from $7.4-18.1 \mu \mathrm{S} / \mathrm{cm}$ and increases as we move from the up-stream section of the river to the down-stream (Table 2) revealing that the activities of the Abattoir and Power Station affect the input of chemical substances into the river that dissociate to form ions capable of conducting electricity. Corroborating this line of thought is the fact that the total dissolved solids (TDS) also increases from $4.1-10.8 \mathrm{mg} / \mathrm{L}$. The TDS and EC values for location A are significantly different from those in location D during the rainy season. However, during the dry season, the EC and TDS values vary from $7-7.8$ 
$\mathrm{mg} / \mathrm{L}$ without following any particular trend. Anthropogenic activities affect the EC and TDS of the water mainly during the rainy season. The $\mathrm{pH}$ of the river varies from 6.1-6.8 in the rainy season but 5.9-6.4 in the dry season indicating slightly more acidic condition in the dry season than the rainy season (Table 2). The rainy season concentration of nitrate is higher than the dry season values unlike for chloride and sulphate indicating possible nitrate input from agricultural activities transported by run-off.

TOC is significantly higher in location D than any other location in the rainy season probably due to coal residue in the premises and adjoining environment of the Thermal Plant that are usually transported during the rainy season into the river.

The water column is contaminated with lead and cadmium at all the locations for all seasons as the concentration of these two heavy metals surpass that of World Health Organization (WHO) maximum allowable contaminant level of $0.01 \mathrm{mg} / \mathrm{L}$ for $\mathrm{Pb}$ and $0.003 \mathrm{mg} / \mathrm{L}$ for $\mathrm{Cd}$. The concentration of copper for all the seasons at all the locations is far lower than the WHO maximum allowable contaminant level of $2 \mathrm{mg} / \mathrm{L}$. Location B is the only location where the concentration of chromium exceeds that of WHO maximum allowable concentration of $0.05 \mathrm{mg} / \mathrm{L}$.

The concentrations of the heavy metals in the river water column at location B of this study in comparison with those of the rivers from other regions of the world are as presented in Table 3. Location B is very important for this comparison because of the use of this location by the locals for swimming and bathing among other uses. Table 3 Concentration of the heavy metals in Oji river water column (mean values for the months of October and January) as compared with the rivers of other regions

\begin{tabular}{|c|c|c|c|c|c|c|}
\hline \multirow[t]{2}{*}{ Geographical region } & \multicolumn{2}{|c|}{$\begin{array}{l}\text { Concentration } \\
\text { column (mg/L) }\end{array}$} & \multirow{2}{*}{$\begin{array}{l}\text { heavy } \\
\mathrm{Cu}\end{array}$} & \multicolumn{2}{|c|}{ metals in water } & \multirow[t]{2}{*}{ References } \\
\hline & $\mathrm{Pb}$ & $\mathrm{Cr}$ & & $\mathrm{Zn}$ & $\mathrm{Cd}$ & \\
\hline Oji river, Nigeria & 0.21 & 0.15 & 0.08 & 0.016 & 0.02 & This study \\
\hline Houjing River Taiwan & 0.025 & 0.0025 & 0.036 & 0.032 & 0.012 & Vu et al., (2018) \\
\hline Pardo River Brazil & 0.0005 & 0.001 & 0.0017 & 0.00126 & 0.001 & Machado et al., (2017) \\
\hline Tembi River, Iran & 1.8 & 0.25 & 0.4 & 0.2 & 0.1 & $\begin{array}{l}\text { Shanbehzadeh et al., } \\
\text { (2014) }\end{array}$ \\
\hline $\begin{array}{ll}\text { Korotoa } & \text { River } \\
\text { Bangladesh } & \end{array}$ & 0.009 & 0.087 & 0.041 & NA & 0.001 & Islam et al., (2015) \\
\hline $\begin{array}{l}\text { Sanandaj-Kamyaran } \\
\text { River, Iran }\end{array}$ & 1.3 & 0.15 & 0.2 & 0.41 & ND & Sharifi et al., (2016) \\
\hline River Godavari, India & 0.0411 & 0.01 & 0.043 & 0.094 & 0.001 & Hussain et al., (2017) \\
\hline River Argungu Nigeria & 0.8 & 0.03 & 1.8 & 0.33 & 0.04 & Obaoh et al., (2015) \\
\hline Tigris River, Turkey & 0.00342 & $<5$ & 0.165 & 0.037 & 0.0014 & Varol and Sen, (2012) \\
\hline Axios River, Greece & 0.0028 & 0.0042 & 0.014 & 0.056 & 0.0011 & $\begin{array}{l}\text { Karageorgis et al., } \\
(2003)\end{array}$ \\
\hline $\begin{array}{l}\text { Mala Welna River, } \\
\text { Poland }\end{array}$ & 0.04 & 0.009 & 0.089 & 0.115 & 0.003 & $\begin{array}{l}\text { Frankowski et al., } \\
(2009)\end{array}$ \\
\hline Odiel River, Spain & 1.98 & 0.18 & 122 & 466 & 0.589 & $\begin{array}{l}\text { Aguasanta et } \\
(2005)\end{array}$ \\
\hline
\end{tabular}

The concentration of copper in the water column of Oji river is far lower than that of the WHO standard and also lower than the values in the rivers of some other regions such as: Tembi River in Iran, River Argungu in Nigeria, Sanandaj-Kamyaran River in Iran and Odiel River in Spain (Table 3). However, the concentrations of lead, chromium and cadmium are higher than the WHO standard but lower than the values recorded in some rivers of other regions of the world such as Tembi River in Iran and Odiel River in Spain (Table 3). The concentration of the heavy metals in Oji River is lower than that of River Argungu in Nigeria except for chromium (Table 3). The concentration values as reported in this work for Oji river having been higher than the WHO standard is expected to pose health risk to the local people who use this water for several purposes as mentioned earlier. Concentration levels exceeding the WHO standards constitute a veritable signal to control anthropogenic activities that have the potential of contributing to the heavy metal input into the river. 
3.2 Water Quality Evaluation Using WQI

The WQI of Oji river around the locations studied is presented in Table 4.

Table 4 WQI of Oji river

\begin{tabular}{|c|c|c|c|}
\hline \multicolumn{4}{|c|}{ October, 2017 (rainy season) } \\
\hline Location & WQI & Rank & Major contaminants \\
\hline A & 364 & Unsuitable for drinking & $\mathrm{TOC}, \mathrm{Pb}$ and $\mathrm{Cd}$ \\
\hline B & 406 & Unsuitable for drinking & $\mathrm{TOC}, \mathrm{Pb}$ and $\mathrm{Cd}$ \\
\hline $\mathbf{C}$ & 241 & Very poor & TOC, $\mathrm{Pb}$ and $\mathrm{Cd}$ \\
\hline D & 830 & Unsuitable for drinking & $\mathrm{TOC}$ and $\mathrm{Cd}$ \\
\hline \multicolumn{4}{|c|}{ January 2018 (dry season) } \\
\hline A & 124 & Poor & $\mathrm{Pb}$ \\
\hline B & 946 & Unsuitable for drinking & $\mathrm{Pb}$ and $\mathrm{Cd}$ \\
\hline C & 607 & Unsuitable for drinking & $\mathrm{Pb}$ and $\mathrm{Cd}$ \\
\hline D & 68 & Good & $\mathrm{Cd}$ \\
\hline
\end{tabular}

During the rainy season, the major contaminants of Oji river in the studied sections of the river were carbonaceous materials (most likely to be mainly hydrocarbons) and toxic metals such as lead and cadmium. The water quality index (WQI) ranging from 241-830 indicates water quality ranking of 'very poor' to 'unsuitable for drinking'. This therefore reveals that Oji river should not be a source of drinking water unless it is treated to eliminate or reduce the concentration of the contaminants to a level below the permissible limits of WHO that ensures insignificant health effects. In the dry season, the major contaminants are cadmium and lead occurring mostly in locations $\mathrm{B}$ and $\mathrm{C}$ where the effects of the Abattoir are most profound. It therefore follows that the activities of the Abattoir are responsible for the increase in WQI around locations B and $\mathrm{C}$. The activities of the Abattoir do not impact location A and have highly reduced effect on location D. The WQI for these two locations (A and D) are 124 and 68 (Table 4) respectively indicating that the water quality can be ranked as poor and good respectively. This ranking is far better than what we have for locations B and C where the WQI is 946 and 607 (Table 4) indicating 'unsuitable for drinking'. However, the fact that the WQI of location D indicates good water for drinking purposes does not mean that the water could be used for drinking without further analysis and treatment. What this study reveals is that so long as the above contaminants are the ones under consideration, the water could be said to be good. However, there are other aspects of water quality such as biological aspect in addition to other physico-chemical aspects which have not been covered in this study. The study has nonetheless provided evidence that anthropogenic activities such as Abattoir deteriorate water quality with known contaminants such as lead and cadmium.

\section{CONCLUSION}

This study determined the values of physico-chemistry parameters and concentration of heavy metals in Oji river and found that the major contaminants in Oji river around the studied locations were lead, cadmium and hydrocarbons. Point source pollution by Abattoir and Power station and non-ponit source pollution by agricultural run-off are potential sources of pollution with these contaminants. The water quality index (WQI) for all the locations during the rainy season varied in the range 241-830 showing that the water ranked from 'very poor' to 'unsuitable for drinking' while during the dry season, the WQI varied in the range 68-946 with only the location downstream the Power station (location D) having WQI value less than 100 of 68 indicating 'good' water. Though the WQI of location D implies good ranking, the water in this location would need to be further analyzed for biological properties before it can be categorically said to be fit for drinking. The other three locations with WQI 124-946 were ranked 'poor' to 'unsuitable for drinking'. This result indicates that the Oji river within the studied locations cannot serve as a source of drinking water unless it is treated before consumption.

\section{ACKNOWLEDGEMENT}

The support received from the SHELL/UNN Centre for Environmental Management \& Control during this study is highly appreciated.

\section{REFERENCES}

Aguasanta, S., Miguel, N.J., Manuel, O., Carlos, C. 2005. Environmental impact of mining activities in the Odiel river basin (SW Spain). $9^{\text {th }}$ International Mine Water Congress, Spain

Ahmad, I., Athar, M., Sarwar, F. 2004. Surface water suitability for drinking purpose in Cholistan Desert. Journal of Biological Sciences, 4, 34-39.

APHA (American Public Health Association) 1998. Standard methods for the examination of water and waste water. $20^{\text {th }}$ Edition, AWWA/NPCF. New York, 5: 24-26. 
Frankowski, M., Sojika, M., Ziola-Frankowska, A., Siepak, M., Murat-Blazjewka, S. 2009. Distribution of heavy metals in the Mala Wetland River system (Western Poland). Oceanological and Hydrobiological Studies, 38, 51-61.

Hussain, J., Husain, I., Arif, M., Gupta, N. 2017. Studies on heavy metal contamination in Godavari river basin. Applied Water Science, 7, 4539-4548.

Iyama, W.A., Edori, O.S. 2013. Water quality index estimate for Isodu river water during dredging in Niger delta, Nigeria. Global Journal of Pure and Applied Sciences, 19, 163-167.

Karageorgis, A.P, Nikolaidis, N.P., Karamanos, H., Skoulikidis, N. 2003. Water and sediment quality assessment of the Axios River and its coastal environment. Continental Shelf Research, 23, 1929-1944.

Lumb, A., Sharma, T.C., Bibeault, J.F., 2011. A review of genesis and evolution of water quality index (WQI) and some future directions. Water quality, Exposure and Health, 3, 11-24.

Machado, C.S., Fregomesi, B.M., Alves, R.I.S, Tomani, K.A.A., Sierra, J., Martins, B.S., Celere, B.S., Mari, M., Schuhmacher, M., Nadal, M., Domingo, J.I., Segura-Munoz, S. 2017. Health risks of environmental exposure to metals and herbicides in the Pardo River, Brazil. Environmental Science and Pollution Research. DOI: 10.1007/S11356-017-9461-z.

Obaroh, I.O. Abubakar, U., Haruna, M.A., Elinge, M.C. 2015. Evaluation of some heavy metals concentration in River Argungu. Journal of Fisheries and Aquatic Science, 10 (6), 581-586.

Qadir, A., Malik, R.N., Husain, S.Z. 2008. Spatio-temporal variations in water quality of Nullah Aik tributary of the river Chenab, Pakistan. Environmental Monitoring and Assessment, 140, 43-59.

Sahu, P., Sikdar, P.K. 2008. Hydrochemical framework of the aquifer in and around East Kolkata Wetlands, West Bengal, India. Environmental Geology, 55, 823-835.

Shanbehzadeh, S., Dastjerdi, M.V., Hassanzadeh, A., Kiyanizadeh, T. 2014. Heavy metals in water and sediment: A case study of Tembi River. Journal of Environmental and Public Health. DOI: $10.1155 / 2014 / 858720$.

Singh, K.P., Malik, A., Sinha, S. 2005. Water quality assessment and apportionment of pollution sources of Comti river (India) using multivariate statistical techmiques-a case study. Analytical Chimica Acta, 538, 355-374

Sutadian, A.D., Muttil, N., Yilmaz, A.G., Perera, B.J.C., 2016. Development of river water quality indices-a review. Environmental Monitoring and Assessment, 188, 58-90

Todd, A.S., Manning, A.H., Verplanck, P.L., Crouch, C., Mcnight, D.M., Dunham, R. 2012. Climate change driven deterioration of water quality in a mineralized watershed. Environmental Science \& Technology, 46, 9324-9332.

Varol, M., Sen, B. 2012. Assessment of nutrient and heavy metal contamination in surface water and sediments of the upper Tigris River, Turkey. Catena, 92, 1-10.

Vu, C.T., Lin, C., Nguyen, K.A., Shern, C-C., Kuo, Y-M. 2018. Ecological risk assessment of heavy metals sampled in sediments and water of the Houjing River, Taiwan. Environmental Earth Sciences, 77,388-398.

WHO, 2008. Water Sanitation and Health https:/www.who.int/water_sanitation_health/publications/2008publications/en/. Accessed December, 2018.

Wu, Z., Wang, X., Chen, Y., Cai, Y., Deng, J. 2018. Assessing river water quality using water quality index in Lake Taihu Basin, China. Science of the Total Environment, 612, 914-922. 